\title{
Marguerite de Navarre, a Nicodemite? Adiaphora and Intention in Heptaméron 30, 65, and 72
}

\author{
Scott Francis \\ University of Pennsylvania
}

This article situates Marguerite de Navarre's Heptaméron within the reformist debate over adiaphora, or theologically indifferent matters made righteous or sinful by the believer's intentions and conscience. It discusses how adiaphora and their implications for Christian liberty and Catholic devotional practices are understood differently by the schismatic reformers (Luther and Calvin) and the non-schismatic reformers (Erasmus, Lefèvre, Roussel), and how Marguerite ultimately sides with the latter in Tales 30, 65, and 72 of the Heptaméron, which emphasize the primacy of intention and conscience over external ceremony. Through the debates among the discussants, Marguerite also uses the opacity of intention to counter the refusal of Calvin and his followers to recognize as adiaphora Catholic practices they regarded as idolatrous, such as placing votive candles in front of statues.

Cet article situe l'Heptaméron de Marguerite de Navarre dans le débat réformiste sur les adiaphora - les choses indifférentes au niveau théologique, qui sont rendues bonnes ou mauvaises par l'intention et la conscience du croyant. Il démontre que les adiaphora et leurs conséquences pour la liberté chrétienne et les rites catholiques prennent un sens tout à fait différent chez les réformateurs schismatiques (Luther et Calvin) de celui que lui donnent les réformateurs non schismatiques (Érasme, Lefèvre, Roussel), parmi lesquels Marguerite se range avec les Nouvelles 30, 65, et 72 de l'Heptaméron, où l'intention et la conscience l'emportent sur la cérémonie externe. À travers les disputes entre les devisants, Marguerite se sert également de l'opacité de l'intention afin de sopposer au refus de Calvin de reconnaître comme des adiaphora les rites catholiques qu'il croyait idolâtres, notamment les cierges votifs.

$\mathrm{f}$ we are to believe the Histoire ecclésiastique des églises réformées au royaume
de France attributed to Théodore de Bèze, Marguerite de Navarre fell from grace in the wake of the Affair of the Placards in October 1534. ${ }^{1}$ Like those around her who had previously worked toward reform, she was cowed by Francis I's anger, and out of deference to her brother's increasing intransigence, she embraced Catholic devotional practices seen as idolatrous by the Reformed Church:

1. This article is based on a paper given at the 60th Annual Meeting of the Renaissance Society of America in New York, 27-29 March 2014. 
[V]oire mesme la Royne de Navarre commença de se porter tout autrement, se plongeant aux idolatries comme les autres, non pas qu'elle approuvast telles superstitions en son cœur, mais d'autant que Ruffi, et autres semblables luy persuadoyent que c'estoient choses indifferentes: dont l'issue fut telle, que finalement l'esprit d'erreur l'aveugla aucunement, aiant fourré en sa maison deux malheureux libertins, l'un nommé Quintin et l'autre Pocques, les blasphemes et erreurs desquels, avec une ample refutation, se trouvent és œuvres de Jean Calvin. ${ }^{2}$

([E]ven the Queen of Navarre began to behave differently, drowning in idolatries like the others, not because she approved of such superstitions in her heart, but because Roussel and others like him persuaded her that they were indifferent matters. As a result, the spirit of error blinded her somewhat, and she harboured in her household two accursed libertines, one named Quintin and the other Pocque, whose blasphemies and errors, along with an ample refutation, may be found in the works of Jean Calvin.)

Marguerite, under the influence of those like her almoner Gérard Roussel, allowed herself to be convinced that Catholic idolatry and superstition were "choses indifferentes," or adiaphora, matters neither inherently righteous nor inherently sinful. She became what Calvin would call a "Nicodemite," someone who tries to maintain a clear conscience while continuing to worship in a church he or she knows to be unholy; the term derisively mocks attempts to justify one's behaviour by citing Nicodemus, the Pharisee who visits Jesus at night in John 3.

If Calvin had a bone to pick with Marguerite, it was Nicodemism, not spiritual libertinism, the charge against which Carol Thysell defends the queen. ${ }^{3}$ It is not clear that Calvin accuses Marguerite of antinomianism, either in the 1545 polemical treatise Contre la secte phantastique et furieuse des libertins qui se nomment spirituelz or in his only surviving letter to Marguerite, dated 28 April 1545. Calvin accuses the preachers Thierry Quintin and Antoine

2. [Théodore de Bèze], Histoire ecclésiastique des Églises réformées au Royaume de France, ed. G. Baum and E. Cunitz, 3 vols. (Nieuwkoop: De Graaf, 1974), 1:36-37 (my translation).

3. Carol Thysell, The Pleasure of Discernment: Marguerite de Navarre as Theologian (Oxford: Oxford University Press, 2000). For further objections to Thysell's thesis, see Gary Ferguson, "Mal de vivre, mal croire: Lanticléricalisme de l'Heptaméron de Marguerite de Navarre," Seizième Siècle 6 (2010): 159n17. 
Pocque of libertinism, not Marguerite, whom he blames only for surrounding herself with supposed libertines. If anything, Calvin implicitly calls Marguerite a Nicodemite. In the 1544 Excuse de Jehan Calvin, à Messieurs les Nicodemites, sur la complaincte qu'ilz font de sa trop grand' rigueur, he denounces "Dames qui nont jamais apprins que d'estre mignardées, et pourtant ne savent que c'est d'ouyr qu'on parle un peu rudement à leur bonne grace" (Ladies who are only used to being handled with kid gloves, and don't know what it's like for someone to speak a bit roughly to their graces). ${ }^{4}$ One could hear in "mignardées" a subtle echo of Francis I's pet name for his sister, "Mignonne."

Moreover, current scholarly understanding of Nicodemism corresponds to the accusation levelled against Marguerite in the Histoire ecclésiastique. While Carlo Ginzburg proposed that Nicodemism was a coherent spiritual movement brought to France by Roussel and Jacques Lefèvre d'Étaples from Strasbourg after their exile in 1525, Carlos M. N. Eire later showed that Calvin's use of the term designates not a coherent theology but a set of common attitudes toward religious compromise and dissimulation. ${ }^{5}$ More recently, Thierry Wanegffelen has shown that the term "Nicodemite" carries a very different connotation from the related, more common temporiseur. A temporiseur acknowledges and is aggrieved by his or her own dissimulation, but alleges temporal circumstances like the risk of persecution as an excuse, whereas Nicodemites assuage their guilty consciences by finding theological justifications for their actions. ${ }^{6}$ According to the Histoire ecclésiastique, Marguerite did the latter through her improper understanding of adiaphora.

This presumed disagreement between Calvin and Marguerite reflects the predominant model for determining the queen's confessional stripes. JeanMarie Le Gall contends that scholarship on Marguerite from the nineteenth century on, driven partly by Protestant bias and partly by the positivist impulse to impose categories and associate the Reformation with modernity while depicting Catholicism as a relic of the Dark Ages, has tended to "[see] the world

4. John Calvin, Three French Treatises, ed. Francis Higman (London: Athlone, 1970), 138 (my translation).

5. Carlo Ginzburg, Il nicodemismo: Simulazione e dissimulazione religiosa nell'Europa del '500 (Turin: Einaudi, 1970); Carlos M. N. Eire, “Calvin and Nicodemism: A Reappraisal," Sixteenth Century Journal 10.1 (1979): 45-69.

6. Thierry Wanegffelen, Ni Rome ni Genève: Des fidèles entre deux chaires en France au XVI' siècle (Paris: Champion, 1997), 70-74. 
through the spectacles of Calvin." To imply that Marguerite was Protestant "in her own way," as does Abel Lefranc, or even to raise the question in exasperation, as does Lucien Febvre, is to agree tacitly with Calvin and his followers that Marguerite held what amount to Protestant beliefs, but adhered to the Church of Rome out of political obligation, loyalty to her brother, and Catholic sensibility. ${ }^{8}$ Le Gall's points are well-taken, but he somewhat mischaracterizes Jonathan Reid's King's Sister - Queen of Dissent, a comprehensive examination of what Reid calls the "Navarrian Network", by intimating that it simply repeats the conclusions of its predecessors by means of a new approach. While Reid does paint a picture of the historical Marguerite as a tireless labourer for reform up to her death in 1549, and while he does claim that Marguerite's network paved the way for the Protestant Reformation in France, he is sensitive to Marguerite's more properly Catholic beliefs, and he shows that what Calvin may have perceived as Nicodemism on the part of Roussel or Marguerite was actually an informed attempt to find common religious ground on divisive issues. ${ }^{9}$

With this in mind, I propose not to place Marguerite in one confessional pigeonhole or another, but to examine her theology from the standpoint of reconciliation. The present study will show that Marguerite's understanding of adiaphora and intention as revealed in three tales of the Heptaméron is at the crux of her search for reconciliation. Drawing on Lefèvre and Roussel, she portrays certain devotional practices as adiaphora to defend them on the basis of the individual believer's intention and to oppose the schismatic position on Christian liberty of Calvin and his followers.

The importance of adiaphora and their varying interpretations to Erasmus and the schismatic reformers (particularly Luther and Calvin) has been acknowledged, but scholars have only just begun to give them full consideration in the context of the French Reformation. Thanks in large part to Rabelais's espousal of Erasmian concepts, studies of adiaphora in sixteenth-century

7. Jean-Marie Le Gall, "Marguerite de Navarre: The Reasons for Remaining Catholic," in A Companion to Marguerite de Navarre, ed. Gary Ferguson and Mary B. McKinley (Leiden: Brill, 2013), 59-61.

8. Abel Lefranc, Les idées religieuses de Marguerite de Navarre d’après son ceuvre poétique (Geneva: Slatkine Reprints, 1969), 33. See also Lucien Febvre, Amour sacré, amour profane: Autour de l'Heptaméron (Paris: Gallimard, 1944).

9. Jonathan A. Reid, King's Sister - Queen of Dissent: Marguerite of Navarre (1492-1549) and her Evangelical Network, 2 vols. (Leiden: Brill, 2009), 2:547. See also Francis Higman, La diffusion de la Réforme en France: 1520-1565 (Geneva: Labor et Fides, 1992), 179. 
French literature have focused on the geste pantagruéline, and in particular on the Tiers Livre. ${ }^{10}$ While there have been no studies devoted to Marguerite that take adiaphora into account, the importance of intention in the queen's oeuvre has not gone unnoticed. ${ }^{11}$ Given that they are morally indeterminate, adiaphora are made righteous or sinful precisely by the intentions and conscience of the individual believer, which are not readily apparent to others, though they are to God. As such, adiaphora and intention are intrinsically connected in the Heptaméron, and nowhere is this connection more apparent than in Tales 30, 65 , and 72, which each reveal a different aspect of Marguerite's thought on the role of adiaphora and intention in soteriology. To understand her thought, we must first understand how she adopts or distances herself from reformist discourse on adiaphora, which may be divided into two strains. On the one hand, Luther and Calvin both make adiaphora a cornerstone of Christian liberty, but take equal pains to distinguish them from practices and beliefs essential or inimical to salvation. On the other hand, Erasmus, Lefèvre, and Roussel insist on the primacy of faith and intention over outward ceremony, and it is this more accommodating approach that Marguerite adopts in the Heptaméron.

\section{Same indifference? Adiaphora in Erasmus, Luther, Calvin, Lefèvre, and Roussel}

The term adiaphora derives from the Greek ảdiápopos, meaning "indistinguishable" or "of no difference" (indifferentia in Latin), and originally designated the external trappings and conventions of Greek society dispensed with by the Cynics. In Stoic philosophy, adiaphora came to denote morally neutral things that are neither virtues nor vices. ${ }^{12}$ While the term does not occur in the New

10. See M. A. Screech, The Rabelaisian Marriage (London: Edward Arnold, 1958), chapter 7. See also Anne-Pascale Pouey-Mounou, Panurge comme lard en pois: Paradoxe, scandale et propriété dans le Tiers Livre, Études Rabelaisiennes 53 (Geneva: Droz, 2013), 95-117.

11. Gary Ferguson and Mary McKinley, “The Heptaméron: Word, Spirit, World," in A Companion to Marguerite de Navarre, 362-63.

12. Montaigne uses the term in the stoic sense when, in his discussion of how dress is determined by habit rather than by reason in "De la coutume et de ne changer aysément une loy receue," he describes clothes as "choses indifferentes" which, if used for their true purpose, would be perfectly reasonable; Michel de Montaigne, Les Essais, ed. Pierre Villey and V.-L. Saulnier (Paris: PUF, 2004), 1.23.118. 
Testament, early Christian and medieval theologians drew on it to explain Paul's remarks on Christian liberty in Romans $14 .^{13}$

In the Reformation, adiaphora are central to Christian liberty as elaborated in Erasmus's Enchiridion, Luther's On the Freedom of a Christian, and Calvin's Institutes of the Christian Religion. For Erasmus, adiaphora are governed by the Enchiridion's Christocentric doctrine, as their righteousness or sinfulness is determined by whether or not the believer intends to strive after Christ through them. While most of the adiaphora Erasmus lists are profane in nature, the category includes such sacred matters as the priesthood and the cult of the saints. For instance, he condemns those who pray to saints in hope of receiving a temporal boon, such as those who pray to Saint Rocco to ward off pestilence, as putting themselves above Christ, but in so doing, he makes a key distinction to clarify why he does not categorically reject the veneration of saints:

I do not condemn those who do these things out of a naïve superstition so much as I do those who pursue them for their own gain. They glorify pious practices that are barely admissible as if they were the paragon of consummate piety, and they encourage for their own advantage the ignorance of the masses, which even I do not entirely condemn, but I will not allow them to lend great importance to things that are merely indifferent or consider matters of little value as being very important. I shall commend them for asking their patron Rocco to keep their lives from harm if they consecrate that life to Christ. I shall commend them the more if they pray for nothing else than an increase in their love of virtue with a corresponding hatred of vice. ${ }^{14}$

While prayers to saints should not be held up as essential to faith so as to satisfy ecclesiastical prestige and avarice, they could potentially stem from a pure (or

13. For more on the philosophical origins of adiaphora, as well as an account of its development through early Christian and medieval thought, see Bernard Verkamp, The Indifferent Mean: Adiaphorism in the English Reformation to 1554 (Athens: Ohio University Press, 1977), chapter 2. See also G. R. Evans, "Sancta Indifferentia and Adiaphora: 'Holy Indifference' and 'Things Indifferent," Common Knowledge 15.1 (Winter 2009): 23-38.

14. Erasmus, “The Handbook of the Christian Soldier," trans. Charles Fantazzi, The Collected Works of Erasmus, ed. John W. O’Malley, 86 vols. to date (Toronto: University of Toronto Press, 1974-), 66:64. 
at the very least naïve) intention to glorify Christ, the touchstone for indifferent matters:

If you examine all your actions and ambitions in accordance with this rule and never stop midway until you reach Christ, you will never stray from the true path and you will never do or tolerate anything in life that cannot be turned into an occasion for the practice of piety. ${ }^{15}$

Since it can become just such an occasion, Erasmus refuses to reject the cult of the saints outright, setting up a precedent for the use of adiaphora to defend Catholic practices that the schismatic reformers would reject.

While Luther does not explicitly mention adiaphora in On the Freedom of a Christian, they clearly inform the treatise, in which his understanding of the concept is as broad as Erasmus's. According to the doctrine of justification by faith alone (sola fide), all good works are adiaphora insofar as they are only made righteous by the believer's intention to please and serve God: "Indeed, if he did not already believe and was not a Christian, then all of his works would count for nothing, but would instead be purely foolish, wanton, damnable sins." ${ }^{16}$ Luther's treatise also shares the Enchiridion's emphasis on charity toward the infirm in faith, and even requires the believer to respect the "innumerable commandments and laws of pope, bishop, monastery, religious foundation, prince, and lord," ${ }^{17}$ inconsequential to salvation though they may be. Just as Christ orders his disciples to pay the tax in Matt. 17:24-27, so too must the Christian set an example by respecting observances of which he has no need for the sake of others. Luther thus takes issue with Catholic piety less because of the nature of its practices than because these practices are often approached with the wrong intention:

For whichever work is not directed toward serving another or suffering under his will (insofar as he does not force one to act contrary to God) is not a good Christian work. As a result, I worry that few foundation

\section{Erasmus, 66:65.}

16. Martin Luther, On the Freedom of a Christian, ed. and trans. Tryntje Helfferich (Indianapolis: Hackett Publishing Company, 2013), 33.

17. Luther, 40. 
churches, monasteries, altars, masses, and testaments are Christian; nor are the fasting and prayers specially made to a number of saints. For I fear that in all of this each one only seeks his own benefit and intends thereby to expiate his sins and to be saved. ${ }^{18}$

For all its similarities with the Enchiridion, though, On the Freedom of a Christian represents the earlier, more conciliatory phase of Luther's career, in which Luther, himself an Augustinian monk, sought to restore doctrinal purity within the Church. It was published in late 1520, a few months before the irreparable break occasioned by Luther's excommunication on 3 January 1521. After the schism, Luther's views hardened, as he condemned monastic vows and took a wife in 1525. Nevertheless, the question of adiaphora remained a pressing one, so much so that it became a singular point of contention at the 1548 Diet of Augsburg and the ensuing Augsburg and Leipzig Interims. In the early 1540s, Calvin also addressed the question, expanding on Luther's clarification that adiaphora are acceptable and even commendable, so long as they are not "contrary to God."

In the 1541 French translation of the Institutes, Calvin explains that Christian liberty "[...] nous instruit de ne faire conscience devant Dieu des choses externes qui par soy sont indifferentes, et nous enseigne que nous les povons ou faire ou laisser indifferemment" ("[...] instructs us not to make the external things which are in themselves indifferent, a matter of conscience before God, and teaches us that it is a matter of indifference whether we do them or not"). ${ }^{19}$ Quoting Romans 14:14, Calvin specifies that adiaphora are entirely a function of the believer's conscience:

Je sçay bien (dit Sainct Paul) qu'il n'y a rien de pollu, sinon à celluy qui estime une chose pollue; car à cestuy-là elle est pollue. Par lesquelles parolles il submet toutes choses externes à nostre liberté, pourveu que l'asseurance de ceste liberté soit certaine à noz consciences devant Dieu.

("I well know," says St. Paul, "that nothing is polluted except for the one who thinks it is so; for to that person it is polluted." By these words he

18. Luther, 41.

19. Jean Calvin, Institution de la religion chrétienne (1541), ed. Olivier Millet, 2 vols. (Geneva: Droz, 2008), 2:1492; Institutes of the Christian Religion, trans. Elsie Anne McKee (Grand Rapids: William B. Eerdmans, 2009), 620. 
subjects all external things to our liberty, provided that the assurance of this liberty is certain in our consciences toward God. $)^{20}$

The conscience alone can ascertain for the individual believer and for God whether an indifferent act is performed with the right intentions. As Michael Screech has discussed, this is how Rabelais, also drawing on Romans 14, has Pantagruel defend marriage and refuse to impute ill will to Panurge in the Tiers Livre:

Chascun abonde en son sens, mesmement en choses foraines, externes et indifferentes, lesquelles de soy ne sont bonnes ne maulvaises, pource qu'elles ne sortent de nos cœurs et pensées, qui est l'officine de tout bien et tout mal: bien, si bonne est et par le esprit munde reiglée l'affection; mal, si hors aequité par l'esprit maling est l'affection depravée.

(Let every man be full of his own ideas, especially in matters alien, extraneous, and indifferent, which are in themselves neither good nor bad, because they do not issue from our hearts and thoughts, which are the workshop producing all good and all evil: good, if good it is, with the disposition ruled by the pure spirit; bad, if by the evil spirit the disposition is depraved. $)^{21}$

However, Calvin and his followers were wary that adiaphora could provide Nicodemites with a convenient excuse for participating in ceremonies like the Catholic mass and the cult of the saints. While Calvin most directly condemns dissimulation in the Excuse à Messieurs les Nicodemites, he first broaches the topic in the 1543 Petit traicté monstrant que c'est que doit faire un homme fidele congnoissant la verité de l'Evangile, quand il est entre les papistes. In response to the attempt of certain persons, including Roussel, to justify Catholic practices with the adiaphora argument, Calvin contends that while some of these practices are merely "foolish and improper," but not offensive to God, others

20. Calvin, Institution, 2:1494; trans. McKee, 621.

21. François Rabelais, Euvres complètes, ed. Mireille Huchon (Paris: Gallimard, 1994), Tiers Livre, 7.372; trans. Donald M. Frame, The Complete Works of François Rabelais (Berkeley: University of California Press, 1991), 278. See also Screech, The Rabelaisian Marriage, 104-12, and Screech, Rabelais (London: Duckworth, 1979), 231-35. 
are utterly idolatrous. The Catholic mass falls into the latter category, as Calvin equates a belief in real presence and transubstantiation with worshipping bread as if it were God. Those who partake of it are in no way comparable to Paul, who allows his head to be shorn in Acts 18:18:

Ceste ceremonie dont sainct Paul usa lors, estoit elle reprouvée de Dieu, ou si elle estoit indifferente, encor pour ce temps là, jusque à ce que l'Evangile fust mieux et plus amplement esclarcy? Il n'y a nul qui ne me concede, que ce n'estoit pas chose mauvaise de soy, ne damnable. Car c'estoit simplement en substance un sacrifice de louange et d'action de grace, qui se faisoit à Dieu. La tonsure et la purgation estoyent bien des umbres de la loy: mais il n'y avoit point d'inconvenient qu'un Chrestien n'en peust user pour edification $[\ldots]$ Or en la messe qu'est-ce qu'il y a de semblable? Je prens la messe pour toutes les autres façons de faire, ou il y a de l'idolatrie evidente ou de la superstition du tout repugnante à la parolle de Dieu. ${ }^{22}$

(This ceremony of which Saint Paul partook, was it condemned by God, or was it still indifferent at that time, until the Gospel was better and more fully revealed? No one can fail to admit that it was not wicked or condemnable in and of itself, for it was essentially a sacrifice made to God out of praise and the action of grace. Tonsure and expurgation were indeed vestiges of the law, but there was nothing wrong with a Christian using them for the purpose of edification [...] Now, what does the mass have in common with this? By the mass, I mean by extension all other practices where there is obvious idolatry or superstition totally repugnant to the word of God.)

Like Erasmus, Calvin acknowledges that adiaphora can be used to edify the infirm or the superstitious. Unlike Erasmus, he insists that the mass cannot be considered indifferent, thus modifying Erasmus's Christocentric doctrine: if any act involves putting something before Christ, it is sinful, and to partake of the Catholic mass is to put bread before Christ and to assume that His sacrifice

22. Jean Calvin, "Petit traicté monstrant que c'est que doit faire un homme fidele congnoissant la verité de l'Evangile, quand il est entre les papistes. Avec une epistre du mesme argument," Joannis Calvini opera quae supersunt omnia, vol. 6, Corpus Reformatorum, vol. 34 (Brunswick: Schwetschke, 1867), 561-62 (my translation). 
must be repeated to have salvific efficacy. In a word, the mass and other Catholic devotional "façons de faire" amount to idolatry, and the believer cannot possibly participate in them with a clear conscience: "[T] $[$ outes ceremonies, qui emportent idolatrie manifeste, sont contraires à la confession d'un chrestien. Pourtant se prosterner devant les images, adorer les reliques des sainctz, aller en pellerinages, porter chandelles devant les ydoles, achepter des messes ou des indulgences, ce sont toutes choses meschantes et desplaisantes à Dieu" (All ceremonies that involve blatant idolatry are contrary to the Christian faith. For this reason, kneeling before statues, adoring the relics of saints, going on pilgrimages, carrying candles in front of images, and purchasing masses or indulgences are all wicked and displeasing to God). ${ }^{23}$

While certain elements of Calvin's writing on adiaphora find their way into the Heptaméron, Lefèvre and Roussel have a much more profound impact on Marguerite, both directly and through the member of the Circle of Meaux who was closest to the queen, Guillaume Briçonnet. ${ }^{24}$ Not surprisingly, Lefèvre's remarks on adiaphora figure most prominently in his commentaries on the Pauline epistles, and much like Luther in On the Freedom of a Christian or Erasmus in De interdicto esu carnium, he devotes particular attention to the question of fasting. Much like Luther, he recommends striving after the edification of others and choosing whether or not to fast accordingly, but places an even stronger emphasis on the individual believer's conscience as the sole criterion for adiaphora:

\begin{abstract}
And so, let your light shine before men, so that they may see your works are good and give glory to your father in heaven. And when you do anything, whether drinking, eating, or whatever else, if you wonder whether you should do it or abstain from it, the Apostle says that you are blessed if, out of an abundance of faith, you do not judge yourself to do wrong or doubt that what you do is sinful..$^{25}$
\end{abstract}

\title{
23. Calvin, "Petit traicté, 585 (my translation).
}

24. Reid stresses that even after the disagreement over Pocque and Quintin, Marguerite continued to draw on Calvin's exegetical works, as did Roussel; 2:559. For more on Marguerite's relationship with Lefèvre and Roussel, see Henry Heller, "Marguerite of Navarre and the Reformers of Meaux," Bibliothèque d'Humanisme et Renaissance 33 (1971): 271-310.

25. "Sic luceat lux vestra coram hominibus, ut videant opera vestra bona et glorificent patrem vestrum qui in coelis est. Et cum aliquid facis, sive bibis, sive comedis, sive quicquid aliud probas id est facere 
Lefèvre, like Erasmus, opts for a broad definition of adiaphora: if good works are done "out of an abundance of faith," that is, with the express purpose of glorifying God, then this intention is more important than the nature of the work itself, and the believer's conscience alone can guarantee the authenticity of this intention.

Roussel picks up on this broad definition in the Familiere exposition $d u$ simbole, de la loy, et oraison dominicale en forme de colloque (ca. 1548-49), a treatise intended to reform preaching in the bishopric of Oloron that takes the form of a catechism between a teacher and a student on the Apostle's Creed, Ten Commandments, and Lord's Prayer. ${ }^{26}$ In it, he addresses devotional practices even more explicitly than Lefèvre:

[...] vraye adoration n'est en cérémonies, parolles et contenances, mais est du cueur régénéré, faict spirituel, bien imbu d'une foy non faincte. Donc, adorer en Esperit et vérité, c'est adorer d'ung cueur pur, d'une conscience bonne et d'une foy non feincte, adorer ce que le cueur fidèle croyt, et non point ce que l'oeil du corps voit.

([...] true worship does not lie in ceremonies, words, and appearances, but is reborn in the heart, made spiritual, and imbued with a genuine faith. So, to worship in spirit and in truth is to worship with a pure heart, a clear conscience, and a genuine faith, to worship what the faithful heart believes, not what the eye of the flesh sees. $)^{27}$

\footnotetext{
aut omittere tentas, beatum te dicit apostolus si ex plenitudine fidei te non iudicas male agere, aut non dubitas, aut haeres peccare in eo ipso quod tentas." Jacques Lefèvre d'Étaples, Epistolae Divi Pauli Apostoli cum commentariis Jacobi Fabri Stapulensis (Paris: François Regnault, 1517), f. 80r (my translation).

26. Roussel also appears to have written a commentary on Romans, now lost. In a letter to Guillaume Farel, dated 5 October 1524, Jacques Pauvan mentions that Roussel wants to publish it in Basel: AiméLouis Herminjard, Correspondance des réformateurs dans les pays de langue française, 9 vols. (Geneva: H. Georg, 1878-97), no. 124, 1:292-93.

27. Gérard Roussel, Familiere exposition du simbole, de la loy, et oraison dominicale en forme de colloque, ms. BnF ff. 419, ff. 41r-41v (my translation). For a transcription and analysis of the Familiere exposition, see Paul J. Landa, “The Reformed Theology of Gérard Roussel, Bishop of Oloron (1536-1555)” (PhD dissertation, Vanderbilt University, 1976).
} 
The implication is twofold: if true worship lies not in rituals and outward appearances ("contenances"), but in the conscience of the believer, then on the one hand, these rituals cannot justify the believer before God in and of themselves, but on the other hand, the believer is free to practise them if he or she is clear of conscience and driven by "foy non feincte." Consequently, it is not a question of changing or eliminating devotional practices, but rather of assuring that they are approached with the correct intention, which is why Roussel's teacher recommends following established ecclesiastical law: "Je suis bien de cest advis, là où n'y a préjudice aulcun ny en foy ny en charité qu’on suyve l'accoustumé" (I am firmly of the opinion that as long as it is not harmful to faith or love, one should follow custom).$^{28}$

While Marguerite likely knew of Erasmus's, Luther's, and Calvin's writings on adiaphora either directly or through intermediaries in the Circle of Meaux, Lefèvre's and Roussel's influence is the most probable and the most palpable. ${ }^{29}$ We know from Marguerite's correspondence that in the 1520 s she actively sought out and distributed Lefèvre's French translations of the Bible and of the Pauline epistles in particular. ${ }^{30}$ Furthermore, given that the Familiere exposition dates from the late 1540s, Roussel's influence, as well as the controversy stirred up by Calvin, might explain why adiaphora only figure

28. Roussel, ff. 78v-79r (my translation).

29. As far as Luther is concerned, we know that a French translation of On the Freedom of a Christian, the Livre tresutile de la vraye et parfaicte subjection des chrestiens (Strasbourg: Johann Schott for Wolfgang Köpfel, before July 1525), was read by the evangelical cell at Metz with whom members of the Circle of Meaux were in contact; Reid, 1:279.

30. In a letter to Philiberte de Savoie that dates from the end of July 1523, Marguerite sends her aunt a copy of Lefèvre's translation of the Gospels, which had been published in Paris by Simon de Colines on 8 June 1523; Pierre Jourda, Répertoire analytique et chronologique de la correspondance de Marguerite d'Angoulême, reine de Navarre (1492-1549) (Paris: Slatkine, 1973), no. 105; for a transcription, see L'Heptaméron des nouvelles de très haute et très illustre princesse Marguerite d'Angoulême, Reine de Navarre, ed. A. Le Roux de Lincy and Anatole de Montaiglon, 4 vols. (Geneva: Slatkine, 1969), 4:187-88. Additionally, in a letter to Marguerite dated 10 January 1524, Briçonnet apologizes for the delay in sending her an illuminated manuscript of Lefèvre's "Epistres sainct Pol translatées," also published by Simon de Colines in November 1523; Guillaume Briçonnet and Marguerite d'Angoulême, Correspondance (1521-1524), ed. Christine Martineau and Michel Veissière, 2 vols. (Geneva: Droz, 1975-79), 2:92. 
in Marguerite's later works, including the Heptaméron. ${ }^{31}$ This is not to imply, though, that Marguerite simply acts as a spokeswoman for Lefèvre or Roussel. On the contrary, she draws on adiaphora for her own purposes in Tales 30, 65, and 72 of the Heptaméron, espousing them both as a remedy for the dangers of superstitious asceticism and as a defense of the very sort of Catholic rites denounced by Calvin in the Petit traicté. At the same time, her tales reveal an awareness of the potential risks of a concept that, in the wrong hands, could be used to justify carnal sins.

\section{Pharisees, publicans, and adiaphora in the Heptaméron}

The third day of the Heptaméron closes with one of the collection's more notorious entries. Tale 30, narrated by Hircan, tells of a devout, austere young widow who aims to punish her son's lasciviousness by having him arrange a tryst with a maid and then taking her place so as to catch him red-handed. However, when he climbs into bed with her, she is overcome by her pent-up desire, and winds up pregnant by him. Mortified by this indiscretion, she sends her son away to fight in Italy, and then gives birth in secret to their daughter, whom she entrusts to the care of her illegitimate brother. Years later, the fighting in Italy subsides, and the widow's son asks to return home. For fear his presence might lead her into temptation yet again, she instructs him not to appear before her "[...] s'il n'estoit marié à quelque femme qu'il aymast bien fort, et qu'il ne regardast poinct aux biens, mais qu'elle fust gentilfemme, c'estoit assez” (“[...] unless he was married to somebody he loved deeply. It did not matter who she was; her fortune was not important; so long as she was a girl of gentle birth, that would be sufficient"). ${ }^{32}$ He then meets and falls in love with his own daughter by his mother, though neither of them are aware of her origin. Since she meets the widow's criteria,

31. Scholarly consensus tends to agree with Pierre Jourda that while Marguerite might conceivably have begun writing certain tales as early as 1515 , she most likely did not work on the collection in earnest prior to settling down in Navarre in 1542 and drawing inspiration for the project from the French translation of the Decameron she commissioned from Antoine Le Maçon, which was published in 1545; see Jourda, Marguerite d'Angoulême, Duchesse d'Alençon, Reine de Navarre (1492-1549): Étude biographique et littéraire, 2 vols. (Paris: Champion, 1930), 2:664-75.

32. Marguerite de Navarre, Heptaméron, ed. Renja Salminen (Geneva: Droz, 1999), 284; trans. P. A. Chilton, The Heptameron (London: Penguin, 1984), 320. All subsequent references are to Salminen's edition and Chilton's translation, hereafter cited in the text. 
they are happily married, much to the widow's chagrin. In desperation, she confesses her sin to the papal legate at Avignon, who advises her to do penance for the rest of her life, but not to speak a word of it to her son and daughter, as their ignorance absolves them from sin.

From a theological standpoint, the tale is interesting less for its double incest than for how Hircan and the other discussants blame the widow's transgression on her mistaken belief that she can resist sin through asceticism when she should confess her weakness and have faith in God alone. While Ennasuite blames the widow's error on her Franciscan spiritual counsellors, Hircan opens the tale by framing her superstitious self-denial as predicated upon ignorance of adiaphora:

Et, tant pout le regrect qu'elle avoit de son mary que pour l'amour de son enfant, delibera de jamais ne se marier. Et, pour fuyr la temptation, ne voullut plus frequenter sinon toutes gens de devotion, car elle pensoyt que l'occasion faisoit le peché, et ne sçavoit pas que le peché forge l'occasion. La jeune dame vefve s'adonna du tout au service divin, fuyant entierement toutes compagnyes de mondanité, tellement qu'elle faisoit conscience d'assister à unes nopces ou d'ouyr sonner les orgues en une eglise. (28081)

(Whether out of sorrow at the loss of her husband or whether out of her love for her child, she had vowed never to remarry. To avoid any situation that might lead to her doing so, she insisted on having nothing to do with anyone except people who were devout. She thought that it is opportunity that leads to sin, and did not realize that it is the reverse: sin manufactures opportunity. This young widow gave herself up entirely to attending divine service. She shunned all worldly gatherings-to such an extent that she even made going to weddings and listening to the organ in church a matter of conscience.) (317)

Emphasizing the widow's fear of temptation spurred by her desire not to remarry, Hircan implies that her conscience is guilty, which is why she sees everything as a potential occasion for sin. If the use of the term "occasion" (occluded by Chilton's choice of "opportunity") calls the adiaphora controversy to mind, the ensuing reductio ad absurdum does so to an even greater extent. The widow is so 
terrified to sin that she abstains from attending weddings and even from listening to organ music in church for fear they might inspire the sort of pleasures of the flesh to which she eventually succumbs with her son. It is also because she fails to understand that "sin manufactures opportunity," not vice versa, that she makes matters even worse by facilitating her son's marriage to the fruit of their illicit union: in her haste to find him a wife and make it impossible for herself to end up back in his bed, she allows him to marry any noble girl he wants, regardless of her means. She is driven by a misguided fear of occasion to sin rather than by a desire to find a suitable match for her son, and his unwitting choice of their daughter is a fitting punishment for her rashness.

In this sense, Tale 30 is highly reminiscent of Calvin's exposition of Christian liberty in the Institutes, which, as we have seen, advises the believer not to "faire conscience" of indifferent matters, and which employs a similar reductio ad absurdum to illustrate why it is necessary to exercise Christian liberty. If someone has scruples about using linen, for example, he will eventually have scruples about using hemp or tow, and if he wonders whether it is too sinfully luxurious to drink good wine, he will eventually no longer be able to bring himself "with peace of conscience" to drink skunked or flat wine, or even water that is especially clean or clear: "Brief, il sera mené jusques là qu'il fera un grand peché de marcher sus un festu de travers" ("In short, he will be led to the point that he will make it a great sin to step on a straw"). ${ }^{33}$ The widow's mortal sin, then, is a result of her failure to recognize that things like weddings and organ music are not occasions to sin, in and of themselves; they are adiaphora, and if they do occasion sin in her, her weakness and her guilty conscience are to blame.

The discussants are in agreement over adiaphora in Tale 30, but a similar consensus is not to be found in Tale 65 . Here, a character whose intentions remain opaque sparks a debate among the discussants over a practice that some see as indifferent and others do not. The tale, told by Géburon, recounts how in the cathedral of Saint-Jean in Lyons, there is a dark chapel with a stone sepulcher (most likely the Holy Sepulcher destroyed during the Wars of Religion in 1562) made up of lifelike statues, some of which are in the form of sleeping soldiers. One summer's day, an actual soldier, drowsy from the heat, falls asleep next to the sepulcher. In comes a devout old woman, lit votive candle in hand. 
Taking the sleeping soldier for a statue, she tries to place her candle on his forehead, and when it fails to stick, she tries to heat up the "statue" by holding the flame to it. When it moves, she cries out that it's a miracle, the church bells start ringing, and her fellow churchgoers come running. When they realize what has happened, most of them laugh, but not, as Géburon explains, the priests: "Mais les prebstres ne s'en peurent contanter, car ilz avoient bien deliberé de faire valloir ce sepulchre et en tirer autant d'argent que du crucifix qui est sur leur pupiltre, lequel on dict avoir parlé. Mais la comedye print fin par la congnoissance de la sottise d'une femme" (464; "But the priests were not too pleased. They had already made up their minds that they should turn their tomb to account and make as much money out of it as they had from their crucifix-the one that hangs over the rood-screen and is supposed to have spoken. However, it only needed one woman's stupidity to become known for that farce to come to an end" [498]).

Based on his choice of words, Géburon intends for his tale to reflect the woman's foolish presumption in keeping with how he introduces it to confirm Ennasuite's remark that there are those who, "pour cuyder myeulx faire que les autres, font pis ou bien le rebours de ce qu'ilz veullent" (463; "thinking they can do better than others, end up worse off or with the opposite of what they wanted" [496]). For Géburon, the old woman mistakes the soldier's reaction for a miracle because she thinks God is recognizing her exemplary devotion. Hircan, true to fashion, piles on, remarking how women always find a way to do wrong, and from this point on, the discussion focuses on how to interpret the old woman's intentions in placing a votive candle, with Oisille defending her and all the men (except Simontaut, who remains silent) accusing her.

Votive candles, one of the practices condemned by Calvin as idolatrous in the Petit traicté, figure elsewhere in Marguerite's later works, namely in the Comédie de Mont-de-Marsan, so titled because it was performed at court in Mont-de-Marsan on Mardi Gras, 13 February 1548. The play opens by drawing a dichotomy between La Mondainne, who lives only to pursue earthly delights, and La Supersticieuse, who strives to mortify her flesh and achieve justification through every ritualistic observance imaginable. She boasts in her opening monologue of the many saints to whom she prays and of how effectively her votive candles allow her prayers to be heard: 
De tous sainctz, oraisons

J'ay pour toutes saisons,

Pour garder et guerir

De tous dangiers et maulx,

D'ennuis et de travaulx

Où je puis encourir.

Puis voici ma neufvaine,

Qui n'est pas chose vainne.

Voiez cez neuf chandelles

S'elles sont allumées

Et que droict les fumées

Voy monter au ciel d'elles,

Je sçay que ma priere

N'est pas mise en arriere,

Mais est receue aux cieulx.

De ces trois qui sont blanches,

Je les garde au dimanche

Dont j'espere bien mieulx.

(To all Saints, orations

I have, for all seasons,

Giving me protection

From all dangers and ills,

And from cares and travails

That I might encounter.

And then last but not least

Is my nine-day vigil.

See these tapers, so fine:

When all nine are burning

And I can see their flame

Go up toward heaven,

I know that my prayer

Will not be cast aside,

And that it was received.

Of the best, that are white, 
I keep three for Sunday,

For which I expect more. ${ }^{34}$ )

As Gary Ferguson sees it, La Supersticieuse's words are indicative of the queen's contempt for "[...] certain contemporary practices associated with the cult of the saints, that she regarded as nothing other than superstitions." ${ }^{35}$ To be sure, the character's pride in her bevy of saints and array of candles is as comically superstitious as her name would suggest, and at first glance, one might be tempted to equate the old woman's belief in a miracle in Tale 65 with La Supersticieuse's belief that smoke rising from her candles means her prayers have been answered, which would be consistent with Géburon's interpretation. However, much like Erasmus in the Enchiridion, Marguerite does not condemn so much the cult of the saints or the use of votive candles as the intention with which La Supersticieuse engages in these practices: she prays to saints to ward off illness, danger, and evil, and she believes that her candles, especially the white ones she saves for Sunday, somehow make God more inclined to answer her prayers in keeping with her belief in justification through good works. This is the key difference between La Supersticieuse and the old woman of Tale 65: whereas the former makes her questionable intentions clear to the viewer through her monologue, the latter's intentions remain opaque. This opacity drives the argument between the discussants, and may account for a particularly striking variant between the manuscript versions of the Heptaméron and the edition prepared by Claude Gruget.

In the manuscripts, Oisille responds to Hircan by comparing the old woman to the widow from Luke 21:1-4 who donates the only two mites she has at the treasury, which pleases Christ more than the gifts of the rich:

Pensez que la pouvre femme cuydoit avoir faict ung beau present à Dieu d'une petite chandelle, ce dist madame Oysille. Dieu ne regarde point la valleur du present, mais le cueur qui le presente. Peult estre que ceste

34. Marguerite de Navarre, “Comédie de Mont-de-Marsan," Euvres complètes, vol. 4 (Théâtre), ed. Geneviève Hasenohr and Olivier Millet (Paris: Champion, 2002), 455, lines 63-80; trans. Régine Reynolds-Cornell, Théâtre Profane (Ottawa: Dovehouse Editions, 1992), 193.

35. Gary Ferguson, Mirroring Belief: Marguerite de Navarre's Devotional Poetry (Edinburgh: Edinburgh University Press, 1992), 101-02. 
bonne femme avoit plus d'amour à Dieu que ceulx qui donnent les grans tresors, car, comme dict l'Evangille, elle donnoit de sa necessité. (464)

"Just imagine, the poor woman thought she was giving God a magnificent present by offering a bit of candle," said Oisille. "God does not look to the value of the present, but to the heart that presents it. It may be that this good woman had greater love of God than those who light huge torches, for, as the Gospel says, she gave of her penury." $(499)^{36}$

Oisille defends placing votive candles before statues on the basis of intention and conscience, the "cueur qui le presente." In keeping with Lefèvre's account of adiaphora, the old woman's act, imperfect though it may be, is done to glorify God, and in Roussel's terms, her act may very well be an example of "adorer d'ung cueur pur."

In Gruget, Oisille's words are put in Hircan's mouth, where they become a haughty indictment of the widow's presumption: "Pensez que la pauvre femme cuidoit avoir faict un beau present à Dieu d'une petite chandelle!' 'Je ne regarde point, dist Oisille, la valeur du present, mais le cueur qui le presente [...]" (464; "Just imagine, the poor woman thought she was giving God a magnificent present by offering a bit of candle!' 'I do not look to the value of the present', said Oisille, 'but to the heart that presents it [...]"' [499]). ${ }^{37}$ Why would Gruget have altered the text in this fashion? Given his usual tendency to make Marguerite more orthodox by removing passages critical of the clergy or that could otherwise have been seen as heretical, I am inclined to think that he makes Marguerite's text an even more explicit defense of a Catholic practice by having the brutal and generally unsympathetic Hircan voice a criticism of the practice reminiscent of Calvin's: the reader knows to take Hircan's words with a grain of salt, especially when he talks about women.

After Hircan, Saffredent remarks that while simplicity is pleasing to God, ignorance is not. The old woman, in his assessment, fails to realize that believing God caused a miracle for her is every bit as detrimental to faith as the fake talking cross the priests hold up as a relic to attract pilgrims. Yet, the cross calls

36. Chilton's translation is based on Gruget's edition; in this instance, I have modified it to match Salminen's edition.

37. Marguerite de Navarre, L'Heptaméron des nouvelles de tresillustre et tresexcellente Princesse Marguerite de Valois, Royne de Navarre, ed. Claude Cruget (Paris: Benoît Prevost, 1560), f. 191v. 
to mind the fact that Oisille herself is well aware of such abuses. In the prologue, she visits Notre Dame de Sarrance simply because she is curious to see a place that she has heard so much about, "Non qu'elle feust sy supersticieuse qu'elle pensast que la glorieuse Vierge laissast la dextre de son filz où elle est assise pour venir demeurer en terre deserte" (2; "Not that she was so superstitious as to believe that the glorious Virgin should leave her seat at her Son's right hand in order to come and take up residence in such a desolate spot" [61]). Oisille is dubious about the Marian apparitions that serve as the primary motivation for pilgrimages to Notre Dame de Sarrance, which makes her espousal of the old woman of Tale 65 all the more compelling: she does not accept without question all elements of Catholic piety, but insists on respecting the opacity of the individual believer's intentions.

Oisille then defends the old woman against Saffredent's charge of ignorance by comparing the votive candle to the practice of making amende honorable for an offense, in which a condemned criminal would confess his crime publicly while kneeling in a public place (often a church), barefoot and bareheaded, wearing only a shirt and carrying a torch or a candle in each hand. From this point of view, the old woman's action is not ignorant, and more importantly, not presumptuous: far from thinking that God has rewarded her for her piety, as the male discussants claim, she is approaching him in humility, acknowledging her own sinfulness, and begging for mercy, not unlike the Publican of Luke 18:9-14. Here, Dagoucin interjects that not everyone has the same understanding of votive candles as Oisille, whose response, the last before Ennasuite changes the subject, is definitive:

"Pleust à Dieu," dist Dagoucin, "que chacun l'entendist aussi bien que vous. Mais j'ay peur que ces pouvres sottes ne le font pas à ceste intencion." Oysille luy respondit: "Celles qui moings en sçavent parler sont celles qui souvent ont plus de sentiment de l'amour et volonté de Dieu. Parquoy, ne fault juger que soy mesmes." (465)

"Would to God," said Dagoucin, "that everybody acted with the same intention as you. But I fear that such is not the case with these poor stupid women." But Oisille replied: "The women who are the least able to talk about it are often the ones who feel more deeply the love and will of God. For this reason one should not judge anyone but oneself." (499) 
Jan Miernowski connects Oisille's interpretation of the tale with the Rabelaisian injunction to interpret the intentions of others "en la meilleure partie," drawing on the concept of the "œil de foy" as described by Briçonnet in his letters to Marguerite. ${ }^{38}$ I would add that this insistence on opacity evokes the adiaphora controversy. Through Oisille, Marguerite raises the possibility that votive candles are an indifferent matter akin to fasting. In so doing, she reconciles the doctrine of sola fide with a practice that Calvin deems offensive to God and contrary to true religion, and while Nancy Virtue is right to connect the tale and its discussion to Marguerite's portrayal and modification of masculinity and femininity, she misses the point by taking Géburon's moral at face value as a reflection of "[...] a certain Reformist critique of the confusing imagery found in traditional Catholic churches, an imagery that was seen as diverting from true faith." ${ }^{39}$ Similarly, while Catherine Randall acknowledges that Tale 65 emphasizes intention over the material object, she then suggests that Marguerite depicts acts of devotion like votive candles as "[...] ritualistic accretions, not derived from Scripture, that can distort intention." ${ }^{40}$ If the priests try to pass off the occurrence as a miracle, the blame lies with them, not with the old woman, and not with the candle, either. In fact, the tale reveals the kind of critique described by Virtue and Randall to be Pharisaic: by showing how eagerly the male discussants jump to conclusions about the old woman's intentions, Marguerite cautions her readers against "seeing the world through the spectacles of Calvin," to return to Le Gall's phrase, and suggests, in keeping with Roussel's exposition of the Eighth Commandment ("Thou shalt not bear false witness against thy neighbour"), that judging opaque intentions to be sinful or occasions to sin is symptomatic of philautia and a lack of agape:

C'est bien le spiritualiser et luy oster l'escorce et le chercher au dedans que d'y voir et recongnoistre la philautie et amour de soy (qui n'est sans mespris du prochain qui nous faict aveugles en nostre faict et oculez ès

38. Jan Miernowski, "L'intentionnalité dans L'Heptaméron de Marguerite de Navarre," Bibliothèque d'Humanisme et Renaissance 63.2 (2001): 45. For Roussel's treatment of the "oeil de foy," see ff. 57r-57v of the Familiere Exposition.

39. Nancy E. Virtue, "Gender and Theology in Marguerite de Navarre's Heptaméron: A Reading of Novella 65," Women in French Studies 12 (2004): 17.

40. Catherine Randall, Earthly Treasures: Material Culture and Metaphysics in the Heptaméron and Evangelical Narrative (West Lafayette: Purdue University Press, 2007), 226-27. 
choses de nostre prochain, qui nous rend propens et inclins à mal sentir et juger de nostre prochain) y estre prohibé comme la souche, origine et racine de toutes suspicions, médisances, calumnies, parjures, faulx jugemens contre le prochain; et y estre requise la dilection mutuelle $[\ldots]^{41}$

(You have truly made [the Eighth Commandment] spiritual and removed its shell to examine it on the inside by recognizing that it forbids philautia or self-love, which inspires a disdain for our neighbour that blinds us to our own doings while making us highly perceptive of his, and which leads us to judge and think ill of him, as it is the stock, origin, and root of all suspicion, slander, calumny, lies, and false judgments of our neighbour, whereas [the Eighth Commandment] requires of us mutual love $[\ldots]$ )

Marguerite goes on to pair this injunction with an awareness of how adiaphora can be abused to justify sin and encourage libertinism in Tale 72, the last tale in the collection, and one that bears a number of similarities with Tale 65 .

Told by Dagoucin, it centres on a nun who is seduced by a smooth-talking monk while they prepare a cadaver for burial, and who accedes to his advances more out of fear and respect for his supposed austerity than out of carnal desire; not unlike the young widow of Tale 30 , she is presented above all as a victim of her own beliefs. She then has a pang of conscience when she tries to pray to the Virgin Mary, and the monk, hearing her sobs, fears she will rob him of his fun: "Dont, pour l'empescher, la vint trouver prosternée devant ceste ymaige, et, la reprenant aigrement, luy dist que, si elle en faisoit conscience, elle se confessast à luy, et qu'elle n'y retournast plus, si elle ne vouloit, car l'un et l'autre sans peché estoit en sa liberté" (506; "To forestall that possibility, he followed her into the chapel, where she lay prostrate in front of the statue of the Virgin. He spoke to her sharply, telling her that if she really had a guilty conscience she should come and confess it to him, and need not repeat the act, if she did not want to, for she was at liberty to choose without sin" [541]). In this respect, the nun is the opposite of Tale 30's young widow: whereas the latter has scruples about matters that are truly indifferent, the nun allows the monk to convince her that fornication is subject to Christian liberty, and that she should only refrain from it "si elle en [fait] conscience." In other words, a monk and a nun breaking 
their vow of chastity with one another is equated with adiaphora in keeping with Calvin's understanding of Nicodemism, though it should be noted that the monk dissuades the nun from her genuine repentance in front of a statue of the Virgin Mary: already, Marguerite simultaneously acknowledges and distances herself from Calvin's fears over the use of adiaphora.

Dagoucin is quick to criticize not only the monk, who clearly twists theology to suit his own nefarious purposes, but the nun, calling her "la sotte religieuse, cuydant satisfaire envers Dieu" (506; "the stupid nun, thinking that she would make amends to God" [541]), and the remainder of the tale concerns her attempts at penance after she becomes pregnant. Her prioress and the monk's prior convince her to go on a pilgrimage to Rome to confess to the pope, fearing that if she stays, she will reveal the priory's unseemly goings-on to the outside world. The nun is thus misled by two successive false promises of absolution: the promise that the monk and his holy water can erase her "pecadille," and the promise that the pope can not only absolve her, but miraculously restore her virginity, which François Cornilliat sees as a parody of medieval Marian miracles like Gautier de Coinci's "De l'abeesse que Nostre Dame delivra de grant angoisse." ${ }^{42}$ While these false promises are obviously abusive, a chance encounter serves to reinforce the nun's earlier repentance before the statue of the Virgin.

On her way to Rome, the nun stops in the cathedral of Saint-Jean in Lyons, the same cathedral in which Tale 65 is set. As it so happens, she arrives there while the Duchess of Alençon (Marguerite) is performing "quelque neufvaine" ("some novena or another"). In fact, the Duchess is kneeling at the rood screen before what is presumably the very same crucifix the priests fallaciously claim is able to speak in Tale 65. How are we to understand Marguerite's representation of herself in this instance? Critics have tended to draw a distinction between the Queen of Navarre and the Duchess of Alençon, suggesting that the older, wiser Marguerite disparages her younger self's attachment to superstitious rituals. Patricia and Rouben Cholakian, for example, read the phrase "quelque neufvaine" as pejorative and argue that novenas were one of the practices from which Marguerite distanced herself under the tutelage of Briçonnet from 1521 
to $1525 .{ }^{43}$ Cornilliat argues that the Marguerite of Tale 72 moves away from the formal practice of religion and toward true charity, noting that this shift parallels how the nun is redeemed as soon as she addresses her prayers to God alone. ${ }^{44}$ These interpretations are certainly plausible, given Marguerite's penchant for self-deprecation, and it is worth recalling how La Supersticieuse of the Comédie de Mont-de-Marsan boasts of using her candles for a novena. Yet, a parallel between La Supersticieuse and the young Duchess of Alençon may not be drawn quite so easily. The Cholakians situate this anecdote in early 1516 during the royal entourage's tour of the kingdom following Francis I's coronation, but Marguerite was also in Lyons in November 1525; the novena may very well be for her first husband, Charles d'Alençon, who fell ill and died there in the wake of his disgrace at Pavia. If the episode possibly occurred after Marguerite's exchange with Briçonnet, it cannot be assumed that the tale documents Marguerite's break with ritualistic practices owing to the Bishop of Meaux's influence. Even more to the point, it is not clear that the Marguerite of Tale 72, any more than the old woman of Tale 65, approaches the novena with the same intentions as La Supersticieuse. In fact, in the context of Marguerite's engagement with the adiaphora controversy, her intervention on the nun's behalf need not be seen as a break with ritual devotion.

The Duchess recognizes the sincerity of the nun's repentance, and is moved to speak to her when she sees her confess her guilt in a manner highly reminiscent of the Publican to whom Oisille compares the old lady in Tale 65: "[elle] se agenoilla; et, en frappant sa coulpe, se print tant à pleurer que c'estoit pitié de louyr, ne criant sinon: 'Hélas! mon Dieu, aye pitié de ceste pouvre pecheresse" (507; "[she] knelt down, and began to beat her breast, weeping most piteously and crying out that she had sinned. 'Alas! My God, have mercy on me a poor sinner!' she sobbed over and over again" [542]). Upon hearing the nun's story, "La Duchesse la reconforta si bien que, sans luy oster la repentance continuelle de son peché, luy mist hors de l'entendement le voyaige de Rome et la renvoya en son prieuré, avecques des lectres à l'evesque $\mathrm{du}$ lieu, pour donner ordre de faire chasser ce religieux scandaleux" (507; “The Duchess so comforted her that, while not discouraging her from continuing

43. Patricia F. Cholakian and Rouben C. Cholakian, Marguerite de Navarre: Mother of the Renaissance (New York: Columbia University Press, 2006), 50.

44. Cornilliat, 83. 
to repent of her sin, she persuaded her to abandon her idea of going to Rome. Then she sent her back to her convent, with letters to the bishop of the diocese, instructing him to have the scandalous monk removed" [542-43]). Marguerite defends the nun's intentions even as she underscores the questionable nature of her devotional practice: even though the pilgrimage typifies ecclesiastical abuse, the nun has the right reasons (genuine contrition and repentance) for wanting to undertake it. The Duchess's intervention should thus be seen not as an attack on pilgrimages in general, but as a way of assuring that justice is done. By the same token, even if corrupt priests have tried to profit from the crucifix by claiming that it can talk, the reader should not assume that the Duchess's prayer before it is insincere or ignorant, nor is it called into question by the discussants. They and the reader only know that she is there to perform a novena, and her recognition of the nun's penance and subsequent charitable intervention imply that her intentions are similar to those of the old lady or the nun. Just as the old woman's intentions are more important than the bare fact of placing a candle before a statue, so too are the Duchess's intentions more important than the bare fact of performing a novena in front of a presumably phony relic. In short, if Marguerite did set out to defend herself against Calvin's accusations in the Heptaméron, Tale 72 would appear to constitute the most salient instance of it.

In my analysis of these tales, my goal has not been to prove that Marguerite was truly Catholic or that she differed from Calvin on certain doctrinal points. Rather, it has been to show how Marguerite uses adiaphora to articulate her own conception of Christian liberty in the Heptaméron, and how this liberty is intertwined with the opacity of the believer's intentions. We may see intention not only as a supreme criterion for salvific efficacy in Marguerite's soteriology, but also as a determining factor in the challenges Marguerite's characters pose to the reader. As in Tales 65 and 72, Marguerite often presents her reader with exercises in opacity-exercises meant to frustrate the reader's attempts to decipher characters' intentions-and this frustration is reflected and compounded by the varied and often opposing interpretations offered by the discussants. It is in this way that Marguerite uses the conventions of her literary genre to offer an alternative to schismatic systematic theology, which categorically refuses to acknowledge the primacy of intention in matters it deems essential or contrary to faith. Given how well it lends itself to this particular intersection of literature and theology, we should consider using adiaphora 
as a critical tool for approaching authors of the evangelical bent with a mind to understanding how they prepare the reader for reconciliation through the opacity of intention. 